punto org

General editor Luigi Maria Sicca

77 
Stefano Armenia

\section{THE VALUE OF SYSTEMS THINKING AND SYSTEM DYNAMICS \\ IN THE MANAGEMENT OF COMPLEX ORGANIZATIONS}

A SELECTION OF CASE STUDIES

Preface by

Edoardo Mollona

Editoriale Scientifica Napoli 
All rights reserved

(C) Copyright 2020 by Editoriale Scientifica s.r.l.

Via San Biagio dei Librai, 39 - 80138 Napoli

www.editorialescientifica.com info@editorialescientifica.com

ISBN 978-88-9391-859-6 


\section{Table of contents}

9 Preface

Edoardo Mollona

15 Introduction

21 1. BACKGROUND ON ORGANIZATIONAL THEORIES

35 2. Systems Thinking, System Dynamics And

ORgANisATIONAL LEARNING: CRUCIAL COMPETENCES FOR MODERN INTELLIGENT ORGANISATIONS

57 3. Systems Thinking and System Dynamics modelling AND SIMULATION

103 4. EXAMPLES OF APPLICATION OF SYSTEMS THINKING AND System DyNAmics

108 4.1. Case studies on the management of organizations

169 4.2. Case studies on Public Policy

199 4.3. Case studies in the domain of sustainability

247 4.4. Case studies on Security issues

283 4.5. Case studies on education and training

293 5. The Smart Model-based Governance approach:

A NEW FRAMEWORK TO SUPPORT ORGANIZATIONS IN MANAGING DECISION-MAKING

313 Conclusion

321 References

333 punto org book series 
Preface

Edoardo Mollona*

In "The value of Systems Thinking and System Dynamics in the management of complex organizations" the author constructs a theoretical and empirical journey into the management of complex organisations through the principles and theories of System Dynamics.

In the short introduction, the author provides the reasons for writing and reading such book. The theme of complexity is crucial nowadays when dealing with the most important and diffused challenges of our times. In this respect, system thinking provides a well-recognised method to deal with such complexity. Moreover, it also provides a mental and philosophical approach to these challenges. Therefore, the author aims to carefully describe the nuances of the discipline following the lessons of the founding fathers and to combine that with many empirical examples of real-world applications derived from his more than 20 years' experience. The combination between a solid theoretical journey with the numerous case studies in the specific context of organisation management appears to be the strength of the book.

In chapter one, before diving into the specific SD matter, the author provides a general background on organisation theories. This background is outlined following an historical perspective, namely the most relevant theories are presented described and

* Full Professor in Business Economics, Department of Computer Science and Engineering, University of Bologna, Italy. 
connected in a step-by-step fashion based on a chronological order. In the flow of the book, this section serves to create the context in which Systems Thinking (ST) and System Dynamics (SD) are born, developed and, specifically, are applied in the cases described in the book.

Chapter two represents the connecting point between the two theoretical domains discussed in the book: organisational management and ST/SD. The interconnections between the two are described, as well as how ST is posed within the organisation management domain. Specifically, the author presents why and how ST/SD is relevant for modern organisations and how those represent a fertile ground for applying ST/SD. By offering a rich repertoire of examples and citations, it is highlighted how concepts of both domains can support each other to provide an explanation for complex problems and to develop governance processes for informed decision-making in contemporary organisations.

In chapter three, Stefano Armenia shows how to handle with proficiency both the topics of Systems Thinking and System Dynamics. His long experience as modeller and as the chairman of the Italian System Dynamics Association emerges in his detailed analysis of the SD discipline. First, the 60-years history of the method is portrayed, starting from J.W. Forrester's first attempts at MIT. Then practical and interesting examples of the application of SD are described in order to provide the meaning and relevance of the methodology. Subsequently, the distinction between Systems Thinking and System Dynamics is described, as well as the overlapping between the two (i.e. shared principles). After that, more technical paragraphs are reported. First, the ST and SD specific concepts and modelling procedures and 'rituals' are outlined. Then, the possibility of participatory SD approaches and their introduction is given. Finally, the modelling techniques and analyses are described with very high details. Specifically, basic systemic behaviours, causal loop diagrams, system archetypes and stock and flow modelling. 
The modelling experiences of the author are well described by the work presented in chapter four. The chapter contains five subsections. Each subsection collects a class of specific case studies in which the author applied SD. The five sections address, respectively, management of organisations, public policy, sustainability, security issues and education and training. Besides the use of SD, all the cases reported have in common that they highlight the importance of governance in complex systems (intended as the process that leads to a policy), as modern organisations are, and how SD can be a practical tool to support decision makers in their activities. The section constitutes a very useful and usable support for practitioners willing to understand how to apply Systems Thinking and System Dynamics to their organizational issues.

Finally, in chapter six, the author explores a new framework - the Smart Model-based Governance approach - which proposes to advance to the 'next' level the process of managing complex organizations. This approach integrates principles from IT, SD and cybernetics in the attempt to develop a new method of governance that benefits from the synergies generated within the three domains. The new approach is expected to be more efficient, 'aware' of complexity and implementable.

Overall, I suggest, the book is a very enjoyable companion to tackle problems of organizations and it reminds us of the importance of recognizing the system structure of challenging issues. In our activity, every day, we are embedded in complex systems but we are not used to recognise them. Neither have we adequate conceptual tools to analyse the way in which our decisions and actions are influenced by the structure of the system in which we are embedded, not to say "captured"!

Specifically, organizations are complex webs of decisions involving a variety of resources and operators. Thus, Systems Thinking is a prerequisite to create a good strategy. Systems Thinking is about developing appropriate mental models to in- 
terpret dynamic interplay among people, decisions and resources. The mental model ought to help decision-makers to capture the deep causal structure that generates events and phenomena thereby foreseeing long-term consequences of decisions and actions.

When Systems Thinking is associated to System Dynamics, which implies the translation of qualitative models into formal models to be simulated with a computer, the value added to support decision-making amplifies even further. Brainstorming following the simulation of models provides the ground to rationalise on blind spots and difficulties that decision-makers face in complex dynamic systems. Experience with simulation allows decision-makers to interpret, under a systemic perspective, the dynamics of organizations as well as dilemmas originating from contemporary management of complex webs of resources.

In this light, a rich body of SD literature concerns the use of computer models as learning laboratories to guide the interpretation of the relationships between a feedback structure and the emerging behaviour produced by that structure. In the book, this tradition is revived and applied to contemporary management issues such as security, sustainability, learning and education.

Therefore, my opinion is that a book that elicits the possible relationships among the study of organizations, Systems Thinking and System Dynamics is welcome to enrich the panoply of conceptual tools available to managers willing to design robust organizations.

In particular, this book scores three important results. First, the author clearly describes the connection between Systems Thinking and System Dynamics and the gains from combining the two approaches. Second, Stefano Armenia offers a vivid representation of the implementation of the approaches by a rich selection of cases. Finally, the use of ST/SD is clearly embedded into organizational and managerial disciplines and offers a good blend of practitioner's acumen and academic background. 
For the above mentioned reasons, I recommend this book both to practitioners willing to enrich their conceptual and methodological toolkit as well as to researchers aiming at fortifying their repertoire of methodological skills aimed at addressing the study of complex problems.

Eventually this book follows the recent Italian edition (edited by Luigi Maria Sicca) of Peter Senge's Classical, The Fifth Discipline, within puntOorg International Research Network, thus testifying that the SD can offer a wide contribution to the literature of Business Organization and HR management. 



\section{References}

Abbot, E. A. (1884). Flatland: A Romance of Many Dimensions. London, Seeley \& Co.

Ackoff, R. L., Emery, F. E. (1972), On ideal-seeking systems. General Systems, 17, 17-24.

Ackoff, R. L. (1994). Systems Thinking and thinking systems. System Dynamics Review, 10(2-3), 175-188.

Adams, H. (1918). A Law of Acceleration. In The Education of Henry Adams (pp. 473-482). New York: Houghton Mifflin.

Andersen, D., Cappelli, D. M., Gonzalez, J. J., Mojtahedzadeh, M., Moore, A. P., Rich, E., ... Zagonel, A. (2004). Preliminary System Dynamics Maps of the Insider Cyber-threat Problem. In Proceedings of the 22nd International Conference of the Systems Dynamics Society (pp. 1-36). Oxford, England.

Andersen, D. F., \& Richardson, G. P. (1997). Scripts for group model building. System Dynamics Review, 13(2), 107-129.

Andersen, D. F., Richardson, G. P., \& Vennix, J. A. M. (1997). Group model building: adding more science to the craft. System Dynamics Review, 13(2), 187-201.

Antunes, P., Kallis, G., Videira, N., \& Santos, R. (2009). Participation and evaluation for sustainable river basin governance. Ecological Economics, 68(4), 931-939.

Argyris, C. (1957). Personality and Organization. New York: Harper \& Brothers.

Argyris, C. (1973). Personality and Organization Theory Revisited. Administrative Science Quarterly, 18(2), 141-167.

Argyris, C., Schön, D. A. (1978). Organisational learning. Reading, Massachusetts, Addison-Wesley.

Armenia S., Charalabidis Y., Falsini D., Lampathaki F., Osimo D., Szkuta K., "Future research directions in Governance and policy making 
under the UE prism of ICT for Governance and Policy Modeling", in Proceedings of the 29th International System Dynamics Conference (ISDC), 2011, Washington DC, USA, ISBN 978-1-935056-08-09

Armenia S, Centra A, Cesarotti V, De Angelis A, Retrosi C (2012). Military Workforce Dynamics and Planning in the Italian AirForce. In: Proceedings of the 30th International System Dynamics Conference (ISDC), 2012, St. Gallen, Switzerland. System Dynamics Society, ISBN: 978-1-935056-10-2.

Armenia S., Misuraca G., Osimo D., Mureddu F., “A New Roadmap for Next-Generation Policy-Making", in Proceedings of the 6th International Conference on Theory and Practice of Electronic Governance (ICEGOV2012), 2012, p.62-66, ISBN 978-1-4503-1200-4

Armenia S., Carlini C., Onori R., Saullo A.P., "Policy Modeling as a new area for research: perspectives for a Systems Thinking and System Dynamics approach?", in Proceedings of the Business Systems Laboratory - 2nd International Symposium, 2014, Rome (Italy), ISBN 9788890824203

Armenia S., Ferreira Franco E., Mecella M., Onori R., “Smart Model-based Governance: from Big-Data to future Policy Making", in Proceedings of the BSLab-SYDIC Workshop 2017, 2017, Rome (Italy), ISBN 9788890824258

Ashby, W. R. (1965), Measuring the internal informational exchange in a system. Cybernetica, 8, 5-22.

Bailey, K. D. (1994). Sociology and the new systems theory: Toward a theoretical synthesis. Suny Press.

Barile, S. (2009), Management sistemico vitale (Vol. 1). Torino, Giappichelli.

Barile, S., Lusch, R., Reynoso, J., Saviano, M., Spohrer, J. (2016), Systems, networks, and ecosystems in service research. Journal of Service Management, 27, 652-674.

Barnard, C. I. (1938). The Functions of the Executives. Cambridge, Massachussets: Harvard University Press.

Barney, J. (1991), Firm resources and sustained competitive advantage. Journal of management, 17, 99-120.

Becker, S. O., Egger, P. H., \& von Ehrlich, M. (2018). Effects of EU Regional Policy: 1989-2013. Regional Science and Urban Economics, 69, 143-152. 
Bertalanffy, L. von (1956), General system theory, General Systems 1, $1-10$.

Beven, K. (2006). A manifesto for the equifinality thesis. Journal of hydrology, 320(1), 18-36.

Bogdanov A.A. (1988), Saggi di scienza generale dell'organizzazione, (Ed. Or. 1921) Napoli, Theoria.

Boyd, D., Crawford, K. (2012), Critical questions for big data: Provocations for a cultural, technological, and scholarly phenomenon. Information, communication \& society, 15, 662-679.

Bratianu, C. (2006), Knowledge dynamics in organisations. In proceedings of the 6th biennal International Economic Symposium SIMPEC, Vol. 1, pp. 51-57.

Bratianu, C., Vasilache, S., Jianu, I. (2006), In search of smart organisations. Management \& Marketing, 1(4).

Braun, W. (2002). The system archetypes. System, 1-26.

Brookes, N., Hickey, R., Littau, P., Locatelli, G., \& Oliomogbe, G. (2015). Using Multi-Case Approaches in Project Management Research: The Megaproject experience. Designs, Methods and Practices for Research of Project Management, 369

Buckley, W. (1967). Sociology and modern systems theory. Prentice-Hall.

Campbell, D. (2001). The long and winding (and frequently bumpy) road to successful client engagement: One team's journey. System Dynamics Review, 17(3), 195-215.

Carli, R., Paniccia, R. M. (1999), Psicologia della formazione. Bologna, Il Mulino.

Cavana, R. Y., \& Clifford, L. V. (2006). Demonstrating the utility of System Dynamics for public policy analysis in New Zealand: the case of excise tax policy on tobacco. System Dynamics Review, 22(4), 321-348.

Chen, C. P., Zhang, C. Y. (2014), Data-intensive applications, challenges, techniques and technologies: A survey on Big Data. Information sciences, 275, 314-347.

Chen, H., Chiang, R. H., Storey, V. C. (2012), Business intelligence and analytics: From big data to big impact. MIS quarterly, 36.

Clarke, A., Margetts, H. (2014), Governments and citizens getting to know each other? Open, closed, and big data in public management reform. Policy \& Internet, 6, 393-417. 
Conant, R.C., Ashby, W.R. (1981), Every Good Regulator of a System Must be a Model of that System. In Conant, R. (Eds.), Mechanisms of Intelligence. Seaside, California, Intersystems Publications, pp. 205-214.

Coyle, G. (1998). The practice of System Dynamics: Milestones, lessons and ideas from 30 years experience. System Dynamics Review, 14(4), 343-365.

Coyle, R. G. (2000). Qualitative and Quantitative Modelling in System Dynamics: Some Research Questions. System Dynamics Review, 16(3), 225-244.

Cyert, R., March, J. (1963), A Behavioral Theory of the Firm. Englewood Cliffs, New Jersey, Prentice-Hall.

Couffignal, L. (1958). “Essai d'une définition générale de la cybernétiq$\mathrm{ue}^{\prime \prime}$, The First International Congress on Cybernetics, Namur, Belgium, June 26-29, 1956, Paris: Gauthier-Villars, 1958, pp. 46-54.

Daft L.R. (1995). Organisation theory and design. Minneapolis-St. Paul, West Pub. Co.

Doyle, J. K., \& Ford, D. N. (1999). Mental models concepts revisited: Some clarifications and a reply to Lane. System Dynamics Review, 15(4), 411-415.

Fayol, H. (1949). General and Industrial Management. London, UK: Sir Isaac Pitman \& Sons Ltd.

Fiddaman T. (2017), A tale of Big Data and System Dynamics. http:// metasd.com/2017/08/a-tale-of-big-data-and-system-dynamics/ (accessed $2^{\text {nd }}$ October 2019).

Fiddaman T. (2017), Data science meets the bottom line - A view from simulation \& System Dynamics. https://www.linkedin.com/pulse/ data-science-meets-bottom-line-tom-fiddaman (accessed $15^{\text {th }}$ September 2019).

Fisher, D. M. (2011). "Everybody thinking differently": K-12 is a leverage point. System Dynamics Review, 27(4), 394-411.

Forrester, J. W. (1961). Industrial Dynamics. New York, MIT Press, and John Wiley \& Sons.

Forrester, J. W. (1968). Principles of Systems. Cambride: Allen Press, Inc.

Forrester, J. W. (1987). Lessons from System Dynamics modeling. System Dynamics Review, 3(2), 136-149.

Forrester, J. W. (1992), Policies, decisions and information sources for modelling. European Journal of Operational Research, 59, 42-63. 
Forrester, J. W. (1994). System Dynamics, Systems Thinking, and soft OR. System Dynamics Review, 10(4), 245-256.

Forrester, J. W. (1999). System Dynamics: the Foundation Under Systems Thinking. Sloan School of Management No. 8 June. Boston, MA.

Forrester, J. W. (2007). System Dynamics - a personal view of the first fifty years. System Dynamics Review, 23(2-3), 345-358.

Forrester, J. W. (2016). Learning through System Dynamics as Preparation for the 21st Century. System Dynamics Review, 32(3-4), 187203.

François C. (1999), Systemics and cybernetics in a historical perspective. Systems Research and Behavioral Science, 16, 203-219.

Gagné, R. M. (1990). Le condizioni dell'apprendimento (Vol. 12). Rome, Armando Editore.

Gary, M. S., Kunc, M., Morecroft, J. D. W., \& Rockart, S. F. (2008). System Dynamics and strategy. System Dynamics Review, 24(4), 407-429.

Ghaffarzadegan, N., Lyneis, J., \& Richardson, G. P. (2010). How small System Dynamics models can help the public policy process. System Dynamics Review, 22(22).

Gilovich, T., Griffin, D., \& Kahneman, D. (2002). Heuristics and biases: The psychology of intuitive judgment. Cambridge University Press.

Grieves, M., Vickers, J. (2017), “Digital twin: Mitigating unpredictable, undesirable emergent behaviour in complex systems," in Transdisciplinary Perspectives on Complex Systems. Berlin, Germany, Springer.

Halal, W. E. (1997), Organisational intelligence: What is it, and how can managers use it. Strategy $\mathcal{E}$ Business, 1-4.

Hammond, D. (2002). Exploring the Genealogy of Systems Thinking. Systems Research and Behavioral Science, 19(5), 429-439.

Harford, T. (2014), Big data: A big mistake? Significance, 11, 14-19.

Hayek, F. (1998). Law, Legislation and Liberty: Volume 1: Rules and Order. London: Routledge.

Hayek, F. (1967). Studies in Philosophy, Politics and Economics. London: Routledge. p. 26.

Hayek, F. (2002). "Competition as a discovery procedure". The Quarterly Journal of Austrian Economics. 5: 12.

He, Z.L., Wong, P.K. (2004), Exploration vs. exploitation: An empirical test of the ambidexterity hypothesis. Organisation science, 15, 481-494. 
Hendrix, M., Al-Sherbaz, A., \& Bloom, V. (2016). Game Based Cyber Security Training: are Serious Games suitable for cyber security training? International Journal of Serious Games, 3(1), 53-61.

Homer, J. B. (1996). Why we iterate: scientific modeling in theory and practice. System Dynamics Review, 12(1), 1-19.

Homer, J. B., \& Richardson, G. P. (2017). On the growth of the System Dynamics field. System Dynamics Review, 33(3-4), 336-346.

Holland, J. (1992), Genetic algorithms. Scientific American, 267(1) 66-72. Houghton, J., Siegel, M., (2015), Advanced data analytics for System Dynamics models using PySD, In Proceedings of 33rd International Conference of the System Dynamics Society, Cambridge, USA, 19-23 July. Huber, G. P., Sutcliffe, K. M., Miller, C. C., Glick, W. H. (1993), Understanding and predicting organisational change. Organisational change and redesign: Ideas and insights for improving performance, 215 - 265.

Jarche H. (2015), The keystone of the smart organisation. http://jarche. com/2015/06/the-keystone-of-the-smart-organisation/ (accessed 17 October 2019).

Junqué de Fortuny, E., Martens, D., Provost, F. (2013), Predictive modelling with big data: is bigger really better? Big Data, 1, 215-226.

Kelly, K. (1994). Out of control: The new biology of machines, social systems and the economic world. Boston: Addison-Wesley.

Lam, A. (2000), Tacit knowledge, organisational learning and societal institutions: An integrated framework. Organisation studies, 21, 487-513.

Lampathaki, F.; Koussouris, S.; Charalabidis, Y.; Askounis, D.; Mouzakitis, S.; Passas, S.; Tsavdaris, H.; Osimo, D.; De Luca, A.; Armenia, S.; "State of the Art in ICT for Governance and Policy Modelling", White Paper of the CROSSROAD Project (FP7), 2010

Lampathaki F., Charalabidis Y., Osimo D., Koussouris S., Armenia S., Askounis D., "Paving the way for future research in ICT for Governance and Policy Modeling" in Proceedings of the 10th IFIP WG 8.5 International Conference, EGOV 2011, Delft, The Netherlands, August/September 2011. Springer Verlag: Heidelberg et al., LNCS \# 6846, 2011.

Lane, D. (2007). The power of the bond between cause and effect: Jay Wright Forrester and the field of System Dynamics. System Dynamics Review, 23(2-3), 95-118. 
Laszlo, E. (1975) "The systems view of the world: The natural philosophy of the new developments in the sciences."

LaValle, S., Hopkins, M. S., Lesser, E., Shockley, R., Kruschwitz, N. (2010), Analytics: The new path to value. MIT Sloan Management Review, 52, 1-25.

Lewin, K. (1947), "Group Decision and Social Change". In Newcomb, T. and Hartley, E. (Eds.), Readings in Social Psychology, New York, Holt, Rinehart \& Winston, 197-211.

Lindeman, T. (2017). A Human Alternative to Pattern Recognition. https://goo.gl/dqsxoh (accessed 10 October 2019)

Likert, R. (1958). Effective Supervision: An Adaptive and Relative Process. Personnel Psychology, 11(3), 317-332.

Likert, R. (1961). New patterns of management. New York, NY, US: McGraw-Hill.

Lyneis, J. M., Cooper, K. G., \& Els, S. A. (2001). Strategic management of complex projects: A case study using System Dynamics. System Dynamics Review, 17(3), 237-260.

March, J. G. (1991), Exploration and exploitation in organisational learning. Organisation science, 2, 71-87.

Martinez-Moyano, I. J., Conrad, S. H., \& Andersen, D. F. (2011). Modeling behavioral considerations related to information security. Computers and Security, 30(6-7), 397-409.

Martinez-Moyano I. J., Richardson I. J. G. (2013) Best practices in system dynamics modelling. Syst Dyn Rev 29(2):102-123

Maslow, A. H. (1943). A theory of human motivation. Psychological Review, 50(4), 370-396.

Maslow, A. H. (1954). Motivation and Personality. Harper \& Row,Publishers, Inc. Mayo, E. (1933). The Human Problems of an Industrial Civilization. New York: The Macmillan Company.

McAfee, A., Brynjolfsson, E., Davenport, T. H., Patil, D. J., Barton, D. (2012), Big data: the management revolution. Harvard business review, 90, 60-68.

McGregor, D. M. (1980). The Human Side of Enterprise. In H. J. Leavitt, L. R. Pondy, \& D. M. Boje (Eds.), Readings in Managerial Psychology (pp. 310-321). Chicago: The University of Chicago Press.

Meadows, D. H., D. L. Meadows, J. Randers, and W. W. Behrens. (1972), The limits to growth. Universe Books, New York, New York, USA. 
Meadows, D. (1998). Indicators and Information Systems for Sustainable Development. A Report to the Balaton Group. Hartland.

Meadows, D. H. (2008). Thinking in systems: A primer. Chelsea green publishing.

Meadows D.H. (2019), Pensare per sistemi. Interpretare il presente, orientare il futuro verso uno sviluppo sostenibile. Traduzione Italiana a cura di Stefano Armenia (SYDIC), Guerini Next

Mintzberg, H. (1994). Rounding the manager job. Sloan Management Review, (Fall), 11-26.

Morecroft, J. (1982). A critical review of diagramming tools for conceptualizing feedback system models. Dynamica, 8(1), 20-29.

Morecroft, J. D. (1983), System Dynamics: Portraying bounded rationality. Omega, 11, 131-142.

Moxnes, E. (2000). Not only the tragedy of the commons: Misperceptions of feedback and policies for sustainable development. System Dynamics Review, 16(4), 325-348.

Moxnes, E. (2004). Misperceptions of basic dynamics: The case of renewable resource management. System Dynamics Review, 20(2), 139-162.

Moxnes, E., \& Jensen, L. (2009). Drunker than intended: Misperceptions and information treatments. Drug and Alcohol Dependence, 105(1-2), 63-70.

Müller, A. (2000). "A Brief History of the BCL". Österreichische Zeitschrift für Geschichtswissenschaften. 11 (1): 9-30

Mureddu F., Osimo D., Misuraca G., Onori R., Armenia, S. (2014). “A Living Roadmap for Policymaking 2.0". In P. Sonntagbauer, K. Nazemi, S. Sonntagbauer, G. Prister, \& D. Burkhardt (Eds.) Handbook of Research on Advanced ICT Integration for Governance and Policy Modeling (pp. 433- 461). Hershey, PA: Information Science Reference.

Nonaka, I., Takeuchi, H. (1995), The Knowledge-Creating Company: How Japanese Companies Create the Dynamics of Innovation, New York, Oxford University Press.

Nordby, A., Øygardslia, K., Sverdrup, U., \& Sverdrup, H. (2016). The art of gamification; teaching sustainability and system thinking by pervasive game development. Electronic Journal of E-Learning, 14(3), 152-168.

Piaget, J. (1967), Logique et Connaissance Scientifique, Encycl. Pleiade, vol. 22, Paris, Gallimard. 
Peck, S., \& Vannix, J. A. M. (1998). Group Model Building: Facilitating Team Learning Using System Dynamics. The Journal of the Operational Research Society, 49(7), 766.

Penrose, E. (1959). The Theory of the Growth of the Firm. New York: John Wiley and Sons.

Peterson, D. W., \& Eberlein, R. L. (1994). Reality check: A bridge between Systems Thinking and System Dynamics. System Dynamics Review, 10(2-3), 159-174.

Pitelis, C. N. (2007). A behavioral resource-based view of the firm: The synergy of cyert and March (1963) and Penrose (1959). Organization Science, 18(3), 478-490.

Plaza-Úbeda, J. A., Pérez-Valls, M., Céspedes-Lorente, J. J., \& Payán-Sánchez, B. (2020). The contribution of systems theory to sustainability in degrowth contexts: The role of subsystems. Systems Research and Behavioral Science, 37(1), 68-81.

Polanyi, M. (1967), The tacit dimension. Garden City, New York, Anchor Books.

Porras. J. I., Robertson, P. J. (1992), Organisation development: Theory, practice and research. In Dunnette M.D. and Hough L.M. (Eds.), Handbook of industrial and organisational psychology (2nd ed., Vol. 3, pp. 719-822), Palo Alto, California, Consulting Psychologist Press.

Porter, M. E. (1985). Competitive Advantage. New York: The Free Press.

Porter, M. E. (1990). The Competitive Advantage of Nations. Harvard Business Review, (March-April), 73-93.

Pruyt, E., \& Kwakkel, J. H. (2014). Radicalization under deep uncertainty: a multi-model exploration of activism, extremism, and terrorism. System Dynamics Review, 30(1-2), 1-28.

Rahmandad, H. (2015). Connecting strategy and System Dynamics: an example and lessons learned. System Dynamics Review, 31(3), 149-172.

Richardson, G.P., \& Andersen, D. F. (1995). Teamwork in Group Model Building. System Dynamics Review, 11(2), 113-137.

Richardson, George P. (1986). Problems with causal-loop diagrams. System Dynamics Review, 2(2), 158-170.

Richmond, B. (1993). Systems Thinking: Critical thinking skills for the 1990s and beyond. System Dynamics Review, 9(2), 113-133.

Richmond, B. (1994). Systems Thinking/System Dynamics: Let's just get on with it. System Dynamics Review, 10(2-3), 135-157. 
Richmond B. (2001), An Introduction to Systems Thinking. Watkinsville, GA, High Performance Systems.

Robinson, S. (2012). Tutorial: Choosing What To Model - Conceptual Modeling For Simulation. In Proceedings of the 2012 Winter Simulation Conference.

Rodič, B. (2017), Industry 4.0 and the new simulation modelling paradigm. Organizacija, 50, 193-207.

Roth, G. L., \& Senge, P. M. (1996). From theory to practice: Research territory, processes and structure at an organizational learning centre. Journal of Organizational Change Management, 9(1), 92-106.

Rouwette, E. A. J. A., Vennix, J. A. M., \& Van Mullekom, T. (2002). Group model building effectiveness: A review of assessment studies. System Dynamics Review, 18(1), 5-45.

Rozinat, A., Van der Aalst, W. M. (2008). Conformance checking of processes based on monitoring real behaviour. Information Systems, 33(1), 64-95.

Rullani, E. (2004), La fabbrica dell'immateriale: produrre valore con la conoscenza. Rome, Carocci.

Schön, D., Argyris, C. (1996), Organisational learning II: Theory, method and practice. Reading, Addison Wesley.

Schwaninger, M. (2001), Intelligent organisations: an integrative framework. Systems Research and Behavioral Science: The Official Journal of the International Federation for Systems Research, 18, 137-158.

Schwaninger, M. (2008), Intelligent organisations: Powerful models for systemic management. Berlin, Germany, Springer Science \& Business Media.

Senge, P. (1990) The Fifth Discipline, Doubleday/Currency, New York, NY.

Senge, P. M., \& Sterman, J. D. (1990). Systems Thinking and Organisational Learning: Acting Locally and Thinking Globally in the Organisation of Future. In Conference on Transforming Organisations. Sloan School of Management.

Senge, P. M. (1992). Mental models. Planning Review, 20(2), 4-44.

Senge, P. M., \& Fulmer, R. M. (1993). Simulations, Systems Thinking and Anticipatory Learning. Journal of Management Development, 12(6), 21-33.Simon H. A. (1971), “Designing Organisations for an Information-Rich World". In Greenberger M. (Eds.), Computers, 
Communication, and the Public Interest, Baltimore, MD, The Johns Hopkins Press, pp. 40-41.

Simon, H. A. (1955), A behavioural model of rational choice. The quarterly journal of economics, 69, 99-118.

Simon, H. A. (1982). The rural-urban population balance again. Regional Science and Urban Economics, 12(4), 599-606.

Simone, C. (2011). Conoscenza e impresa: percorsi strategici, modelli organizzativi, casi di studio. Padova, Cedam.

Stave, K. (2010). Participatory System Dynamics modeling for sustainable environmental management: Observations from four cases. Sustainability, 2(9), 2762-2784.

Sterman, J. D. (2000). Business Dynamics: Systems Thinking and Modeling for a Complex World. Boston: Irwin/McGraw-Hill.

Sterman, J. D. (1989). Modeling Managerial Behavior: Misperceptions of Feedback in a Dynamic Decision Making Experiment. Management Science, 35(3), 321-339.

Sterman, J., Franck, T., Fiddaman, T., Jones, A., McCauley, S., Rice, P., ... Rooney-Varga, J. N. (2015). WORLD CLIMATE: A Role-Play Simulation of Climate Negotiations. Simulation \& Gaming, 46(3-4), 348-382.

Sterman, J. D. (2002a). All models are wrong: reflections on becoming a systems scientist. System Dynamics Review: The Journal of the System Dynamics Society, 18(4), 501-531.

Sterman, J. D. (2002b). Dana Meadows: thinking globally, acting locally. System Dynamics Review, 18(2), 101-107.

Stroh, D. P. (2015). Systems Thinking For Social Change. Chelsea Green Publishing.

Sweeney, L. B., \& Sterman, J. D. (2000). Bathtub dynamics: Initial results of a Systems Thinking inventory. System Dynamics Review, 16(4), 249-286.

Tao, F., Cheng, J., Qi, Q., Zhang, M., Zhang, H., Sui, F. (2018), Digital twin-driven product design, manufacturing and service with big data. The International Journal of Advanced Manufacturing Technolo$g y, 94,3563-3576$.

Taylor, F. W. (1911). The principles of Scientific Management. Norwood Mass, US: The Plimpton Press

Tarantino, A (2017), Organisational Learning, http://nuovadidattica.lascuolaconvoi.it/agire-organizzativo/5-il-lavoro/organisational-learning/\#_ftn1 (accessed on 26 September 2019). 
Thomson C., Richardson N. (2017), The Intelligent Organisation. https:// emergentaction.com/the-smart-organisation/ (accessed 06 June 2019).

Tichy, N. M. (1983). Managing strategic change: Technical, political, and cultural dynamics (Vol. 3). New York, John Wiley \& Sons.

Ulrich, W. (2016). Critical Systems Thinking as Critically Systemic Discourse. The Journal of the Operational Research Society, 54(4), 325-342.

Umpleby, S. (2008). "Definitions of Cybernetics". In The Larry Richards Reader 1997-2007. pp. 9-11. http://polyproject.wikispaces.com/ file/view/Larry+Richards+Reader+6+08.pdf

Unesco, U. N. E. P. (1983), IEEP, Environmental Module on Environmental Problems in Cities, Paris.

Van Der Aalst, W. (2011). Process mining: discovery, conformance and enhancement of business processes (Vol. 2). Heidelberg, Springer.

Vennix, J. A. M. (1996). Group model building. Chichester: Wiley.

Vernadskij, V. I. (1994), Pensieri filosofici di un naturalista. Edizioni Teknos.

Videira, N., Antunes, P., Santos, R., \& Lopes, R. (2010). A participatory modelling approach to support integrated sustainability assessment processes. Systems Research and Behavioral Science, 27(4), 446-460.

Videira, N., Lopes, R., Antunes, P., Santos, R., \& Casanova, J. L. (2012). Mapping Maritime Sustainability Issues with Stakeholder Groups. Systems Research and Behavioral Science, 29(6), 596-619.

Watzlawick, P., Weakland, J. H., Fisch, R. (1974), Change: Principles of problem formation and problem resolution. New York, Norton.

Weber, M. [1922](1978). Economy and Society. Berkeley: University of California Press.

Wheat, D. (2010). What can System Dynamics learn from the public policy implementation literature? Systems Research and Behavioral Science, 27(4), 425-442.

Wiener, N. (1948). Cybernetics: Or Control and Communication in the Animal and the Machine. Cambridge, Massachusetts: MIT Press.

Williamson, Oliver E. (1975). Markets and Hierarchies: Analysis and Antitrust Implications. New York: The Free Press.

Wolstenholme, E. (2004). Using generic system archetypes to support thinking and modelling. System Dynamics Review, 20(4), 341-356. 


\section{punto org book series}

www.puntoorg.net

1. L.M. Sicca (Ed.) Leggere e scrivere organizzazioni. Estetica, umanesimo e conoscenze manageriali (with an afterword by F. Piro), 2010.

2. L.M. Sicca, Alla fonte dei saperi manageriali. Il ruolo della musica nella ricerca per l'innovazione e per la formazione delle risorse umane, 2012.

3. A. Di Scipio, Pensare le tecnologie del suono e della musica (with a preface by R. Diana), 2012.

4. R. Musto, Scienza Natura Cambiamento (with a preface by $\mathrm{M}$. Nicodemi), 2012.

5. R. Musto, Novalis. L'assoluto e le cose (with a preface by C. Albarella and an afterword by G. Imbruglia), 2013.

6. Aa.Vv. ${ }^{\text {II }}$ I linguaggi dell'organizzare. Musica e testo tra dono e disinteresse, 2013.

7. B. Masiello, Fiducia nelle reti. Strategie per la crescita nei mercati internazionali delle PMI (with a preface by F. Izzo), 2013.

8. Aa.Vv. ${ }^{\mathrm{II}}$, Tavola rotonda. Umanesimo del management attraverso gli occhi dell'altro, 2013.

9. M. Calcagno, Narrare terre di mezzo. Management arte design (with a preface by S. Faccipieri and an afterword by A. Comacchio), 2013.

10. R. Diana, Disappartenenza dell'Io. Filosofia e musica verso Samuel Beckett (with a preface by L.M. Sicca), 2014.

${ }^{1}$ Contributors Per Olof Berg and Kristian Kreiner, Robert W. Witkin, Barbara Czarniawska and Carl Rhodes, Ken Starkey and Sue Tempest, John Hendry, Karin Knorr Cetina.

"I Contributors Luigi Maria Sicca, Umberto di Porzio, Rosario Diana, Agostino Di Scipio, Mariella De Simone, Bernardo Maria Sannino, Chiara Mallozzi, Lorenzo Pone, Giancarlo Turaccio.

"I Contributors Luigi Maria Sicca, Francesco Izzo, Maura Striano, Giulia Dell'Aquila, Felice Casucci, Francesco Perillo, Rosario Diana, Paola Giampaolo, Davide Bizjak, Gilberto-Antonio Marselli, Franco Vitelli, Maria Rosaria Napolitano. 
11. Aa.Vv. ${ }^{\text {Iv }}$, Sergio Piro. Maestri e allievi, 2014.

12. F.D. Perillo (Ed.) ${ }^{\mathrm{v}}$, Impresa imperfetta, 2014.

13. L.M. Sicca, L. Zan (a cura di) ${ }^{\mathrm{v}}$, Management Arti Culture. Resoconto del primo anno del GSA - Accademia Italiana di Economia Aziendale, 2014.

14. M. Iaccarino, Un mondo assetato. Come il bisogno di acqua plasma la civiltà (with a preface by F.P. Casavola and an afterword by A. Giannola), 2015.

15. F. Piro, Manuale di educazione al pensiero critico. Comprendere e argomentare (with a preface by T. De Mauro), 2015.

16. F. D'Errico, Fuor di metafora. Sette osservazioni sull'improvvisazione musicale (with a preface by P. de Vita and an afterword by M. Maldonato), 2015.

17. E. Mollona, Computer Simulation in Social Sciences. A logic of enquiry (with a preface by L.M. Sicca; foreword by G. Colombo and an afterword by D. Secchi), 2015.

18. S. Oliverio, L.M. Sicca, P. Valerio ${ }^{\mathrm{VI}}$, Transformare le pratiche nelle organizzazioni di lavoro e di pensiero (with a preface by G. Manfredi), 2015.

19. P. Valerio, C. Bertolazzi, P. Marcasciano (Ed.) ${ }^{\mathrm{v} \amalg}$, Transformare l'organizzazione dei luoghi di detenzione. Persone transgender e gender nonconforming tra diritti e identità (with a preface by L.M. Sicca), 2016.

rv Contributors Giuseppe Cantillo, Tullio De Mauro, Aldo Masullo, Mariapaola Fimiani, Teresa Capacchione, Antonio Mancini, Roberto Beneduce, Enrico De Notaris, Fulvio Marone, Dario Stefano Dell'aquila, Luigi Maria Sicca, Francesco Piro.

v Contributors Pier Luigi Celli, Eugenio Mazzarella, Enzo Rullani, Luigi Maria Sicca, Francesco Varanini.

vi Contributors Stefano Baia Curioni, Paola Dubini and Ludovica Leone, Sara Bonini Baraldi and Luca Zan, Monica Calcagno and Luigi M. Sicca, Donata Collodi, Francesco Crisci and Andrea Moretti, Roberto Ferrari and Alessandro Hinna, Francesco Giaccari, Francesca Imperiale and Valentina Terlizzi, Daniele Goldoni, Pamela Palmi.

vi Contributors Anna Lisa Amodeo, Christian Ballarin, Davide Bizjak, Ilaria Boncori and Paolo Fazzari, Rossella Bonito Oliva, Simone Cangelosi, Marco De Giorgi, Guglielmo Faldetta, Vittoria Fiorelli, Stefano Maltese, Porpora Marcasciano, Piergiorgio Masi, Antonia Monopoli and Chiara Repetto, Andrea Morniroli, Edoardo Mollona, Cristiano Scandurra, Luca Solari, Maria Spanò, Maria Gigliola Toniollo.

viI Contributors: Paolo Valerio, Giuseppe Ferraro, Carmen Bertolazzi, Alexander Hochdorn, Porpora Marcasciano, Luca Chianura, Damiana Massara, Daniela A. Nadalin, Adriana Godano, Luca Chianura, Vittoria Colonna, Elia De Caro, Tito Flagella, Anna Lorenzetti. 
20. M.R. Napolitano, V. Marino (Ed.) ${ }^{\mathrm{Ix}}$, Cultural Heritage e Made In Italy. Casi ed esperienze di marketing internazionale (with a preface by G. Volpe and an afterword by A. Mattiacci), 2016.

21. M. Lusiani, Discourses of Planning (with a preface by L. Zan and an afterword by A. Langley), 2016.

22. F.D. Perillo, Simposio manageriale (with a preface by A. Masullo and an afterword by P.L. Celli), 2016.

23. P. Ferri, I commissariamenti nel settore culturale italiano. Obiettivi, azioni, risultati (with a preface by L. Zan and an afterword by G. Grossi), 2016.

24. L. Pareschi, Controcampo letterario. Strategie di intermediazione e accesso all'industria editoriale (with a preface by P. Dubini and an afterword by G. Colombo), 2016.

25. G.-A. Marselli, Mondo contadino e azione meridionalista. L'esperienza del Gruppo Rossi-Doria a Portici (with a preface by E. Mazzetti and an afterword by F. Vitelli), 2016.

26. F. Accardi ${ }^{x}$, Risk and Control Governance. A value-creation perspective (with a preface by A. De Nicola; an introduction by V. Atella and an afterword by S. Bozzolan), 2017.

27. I. Boncori (Ed.) ${ }^{\mathrm{x}}$, LGBT+ Perspectives. The University of Essex Reader, (with a foreword by A. Forster), 2017.

28. A. Papa, “... Una cappella cavata dentro il monte...". Storia minima del complesso monastico di S. Lucia al Monte (with a preface by L. d'Alessandro), 2017.

ix Contributors Loretta Battaglia, Giuseppe Bertoli, Roberta Biandolino, Michelle Bonera, Enrico Bonetti, Mauro Cavallone, Elena Cedrola, Marta Cerquetti, Maria Chiarvesio, Anna Codini, Emanuela Conti, Eleonora Di Maria, Barbara Francioni, Antonella Garofano, Francesco Izzo, Giulia Lanzilli, Gaetano Macario, Giulio Maggiore, Francesca Magno, Vittoria Marino, Barbara Masiello, Michela Matarazzo, Alberto Mattiacci, Marta Maria Montella, Fabio Musso, Maria Rosaria Napolitano, Alessandro Pagano, Tonino Pencarelli, Giovanna Pegan, Michele Quintano, Riccardo Resciniti, Marcello Risitano, Angelo Riviezzo, Savino Santovito, Elisabetta Savelli, Michele Simoni, Annarita Sorrentino, Raffaella Tabacco, Donata Vianelli.

${ }^{x}$ Contributors Roberto Rosato, Nicoletta Mincato, Carlo Nicoletti, Paolo De Paolis, Alessandro Salibra Bove.

хг Contributors Alison J. Taylor-Lamb, Jamie Raines, Thomas Currid and Carl Chandra, Martin Harrison and Peter Martin, Rainer Shulze, Fleur Jeans and Teresa Eade, Tuesday Wats, Amy Anderson, Sco Lawley. 
29. R. Diana, L.M. Sicca, G. Turaccio ${ }^{\mathrm{xI}}$, Risonanze. Organizzazione, musica, scienze (with a preface by A. Strati and an afterword by A. Solbiati), 2017.

30. F. D'Errico, Armonia funzionale e modalità. Rudimenti per l'improvvisazione a indirizzo jazzistico (with a foreword by F. Piro and a preface by R. Grisley), 2017.

31. M. Calcagno, Interpreting Innovation. Design Creativity Art (with a foreword by F. Izzo; preface by A. Moretti and an afterword by J. Metelmann), 2017.

32. G. Balirano, Gardai \& Badfellas: The Discursive Construction of Organised Crime in the Irish Media (with a foreword by L.M. Sicca), 2017.

33. M.C. Mason, A. Moretti, Tattoo Management. Mercati, attori, valore, 2017.

34. P. Testa, Innovazione del modello di business. Le dimensioni latenti nella letteratura di management (with a preface by L. Cantone), 2017.

35. L. Massa, Viva 'o re! Municipio e dintorni (with an introduction by L.M. Sicca; preface by E. Borgonovi and an afterword by C. Mochi Sismondi), 2017.

36. F. Pavan, Memini. Piccole storie di storia della musica (with a foreword by E. Mazzarella; preface by R. Alessandrini and an afterword by V. Moroni), 2017.

37. C. Mallozzi, D. Tortora ${ }^{\mathrm{x} I}$, La bottega del suono. Mario Bertoncini. Maestri e allievi (with a preface by M. Nicodemi and an afterword by L.M. Sicca), 2017.

38. G. Melis, Collaborazione e apprendimento nei processi di co-creazione di valore. Il caso delle destinazioni turistiche (with a preface by M.R. Napolitano and an afterword by B. Argiolas), 2018.

xII Contributors Davide Bizjak, Dario Casillo, Rosario Diana, Umberto Di Porzio, Agostino Di Scipio, Chiara Mallozzi, Mario Nicodemi, Lorenzo Pone, Rosalba Quindici, Sonia Ritondale, Tommaso Rossi, Bernardo Maria Sannino, Luigi Maria Sicca, Cristian Sommaiuolo, Giancarlo Turaccio, Paolo Valerio.

xIII Contributors Mario Bertoncini, Davide Bizjak, Gianmario Borio, Pietro Cavallotti, Andrew Culver, Francesco D'Errico, Charles de Mestral, Michelangelo Lupone, Chiara Mallozzi, Alessandro Mastropietro, Mario Nicodemi, Luigino Pizzaleo, Lorenzo Pone, Ingrid Pustijanac, John Rea, Bernardo Maria Sannino, Luigi Maria Sicca, Daniela Tortora. 
39. G. Viglia, A.C. Invernizzi, Il ruolo dell'hubris nella gestione imprenditoriale (with a preface by C. Mauri), 2018.

40. T. Russo Spena, C. Mele, Practising innovation. A Sociomaterial View (with a foreword by E. Gummesson; preface by J. Spohrer and an afterword by P. Stampacchia), 2018.

41. I. Boncori, Race, Ethnicity and Inclusion. The University of Essex Reader (with a foreword by A. Forster and a postface by M. Śliwa), 2018.

42. K.E. Russo, The Evaluation of Risk in Institutional and Newspaper Discourse. The Case of Climate Change and Migration (with a preface by G. Bettini), 2018.

43. R. Pera, When Consumers get Creative. Cocreation in the Individual and Collective Realm (with a preface by D. Dalli), 2018.

44. F. Piro, L.M. Sicca, P. Maturi, M. Squillante, M. Striano (Eds.) ${ }^{\mathrm{xrv}}$, Sfide didattiche. Il pensiero critico nella scuola e nell'università (with a preface by F. Sabatini), 2018.

45. R. Quaglia, Bravi ma basta! Su certe premesse, promesse e catastrofi culturali (with a foreword by L.M. Sicca; preface di J. Mills and a postface by F. Barca), 2018.

46. B. Czarniawska, La narrazione nelle scienze sociali (First Italian Edition by L.M. Sicca, F. Piro and I. Boncori), 2018.

47. F. Longobardi, Le affinità del lessico, 2018.

48. G. Calogero ${ }^{\mathrm{xv}}$, L'abbiccì della democrazia. E altri scritti (Ed. by R. Trombelli), 2018.

49. V. Fiorelli (Ed.) ${ }^{\mathrm{xvI}}$, Margini e confini. Attraversamenti di metodi $e$ linguaggi tra comunicazione, didattica e possibilità della ricerca (with a preface by L. d'Alessandro), 2018.

xiv Contributors Maura Striano, Rosaria Capobianco and Maria Rita Petitti, Francesco Piro, Roberta Gimigliano, Monica Mollo, Gerarda Fattoruso, Maria Incoronata Fredella, Maria Grazia Olivieri, Massimo Squillante and Antonia Travaglione, Pietro Maturi, Fabio Maria Risolo, Luca Marano, Luigi Maria Sicca, Giuseppe Recinto, Mario Nicodemi, Chiara Mallozzi and Luigi Marolda, Luigi Proserpio, Davide Bizjak, Paolo Canonico, Stefano Consiglio, Ernesto De Nito and Teresa Anna Rita Gentile, Natascia Villani.

xv Contributors Francesco Piro, Gennaro Sasso.

xvi Contributors Giuliano Amato, Gianluca Bocchi, Massimo Abdallah Cozzolino, Diego Davide, Lucia Donsì, Amedeo Feniello, Vittoria Fiorelli, Luigi Manconi, Roberta Morosini, Gianmarco Pisa, Ciro Pizzo, Leopoldo Repola, Stefano Rodotà, Francesco Varanini. 
50. G. Cundari, Il mondo: una bella prigione? Riflessioni geografiche, 2018.

51. M. Nicotra, Il canto dei sireni. Invenzioni trans/singolari e psicoanalisi lacaniana (with a preface by A. Vicens and an afterword by $\mathrm{P}$. Guazzo), 2019.

52. L. Marano, Come parlano i giovani. Una indagine di sociolinguistica urbana (with a preface by P. Maturi), 2019.

53. M. Floris, R. Tronci, C. Dessi, A. Dettori, Imprese familiari e imprenditorialità. La sfida del cambiamento (with a preface by F. Cabiddu), 2019.

53. M. Floris, R. Tronci, C. Dessi, A. Dettori, Imprese familiari e imprenditorialità. La sfida del cambiamento (with a preface by F. Cabiddu), 2019.

54. T.T. Lennerfors, L. Mitchell (Eds.) $)^{\mathrm{xvI}}$, SCOS. Searching Collectively for Our Soul, 2019.

55. Aa.Vv. ${ }^{\text {xvı }}$, Lucio Sicca. Maestri e allievi, 2019.

56. E. Sacerdote ${ }^{\mathrm{xIx}}$, Breviario sul pensiero strategico. Discorsi e percorsi per conquistare il futuro migliore, 2019.

57. M.E. Santagati, L. Zan (Eds.) ${ }^{\mathrm{xx}}$, Imprenditorialità e settore museale. Esperienze e prospettive di cambiamento, 2019.

58. F.D. Perillo, D. Bizjak, L'impresa nello zaino. La Elmeco da vico San Liborio al mondo, 2019.

xvi Contributors Beatriz Acevedo, Omar Aktouf, Noortje van Amsterdam, Per Olof Berg, Davide Bizjak, Ilaria Boncori, Jo Brewis, Peter Case, Patricia Ehrensal, Ken Ehrensal, Hugo Gaggiotti, Silvia Gherardi, Claes Gustafsson, Campbell Jones, Nina Kivinen, Monika Kostera, Kristian J Kreiner, Thomas Taro Lennerfors, Marcus Lindahl, Steve Linstead, Tomek Ludwicki, Takashi Majima, Laura Mitchell, Albert J. Mills, Jean Helms Mills, Luc Peters, Alf Rehn, Harriet Shortt, Luigi Maria Sicca, Antonio Strati, Sam Warren, Robert Witkin, Anthony R. Yue, Peter Zackariasson.

xvm Contributors Luigi Guatri, Giovanni Zanetti, Adriano Giannola, Franco Amatori, Renato Mele, Francesco Testa and Riccardo Mercurio; Enzo Rullani, Paolo de Vita, Salvatore Vicari, Luigi Cantone, Pierpaolo Testa and Vincenzo Basile; Marco Ferretti, Maria Rosaria Napolitano, Francesco Izzo, Enrico Bonetti, Antonio Capaldo, Paolo Calvosa, Davide Bizjak.

xix Contributors Stefano De Luca and Guido Solza.

xx Contributors Chiara Bombardieri, Paola Degli Esposti, Mariagabriella Fornasiero, Valentina Galloni, Alessandro Gazzotti, Claudia Giordani, Federica Guidi, Annalisa Managlia, Umberto Mossetti, Michele Recanatini, Elisa Schiavina, Stefania Spaggiari, Patrizia Tomba, Cinzia Vecchi. 
59. F.D. Perillo, D. Bizjak, R.A. Tundo, The Company in the Backpack. Elmeco's, from Vico San Liborio to the World, 2019.

60. M. Castro Espín ${ }^{\mathrm{xx}}$, Persone transessuali a Cuba (with a preface by L.M. Sicca), 2019.

61. G. van Wulfen, La spedizione per innovare. Un kit di strumenti visual per far partire l'innovazione (First Italian Edition by M.V. Colucci, A. Forciniti, L. Migliola and L. Rossi), 2019.

62. P. Senge ${ }^{\mathrm{xxI}}$, La quinta disciplina: l'arte e la pratica dell'apprendimento organizzativo (ed. 2006), (Italian Edition by L.M. Sicca), 2019.

63. V. Basile, Marketing Performance Measurement in FMCG Share of Wallet in Retailing Industry (with a foreword by L. Cantone), 2020.

64. A. Moretti, R. Tabacco, I Menuzzo e C AME. Una storia di passione per il prodotto, $i$ clienti e le relazioni (with an afterword by R. Samiolo), 2020.

65. B. Masiello, Il lato oscuro delle reti. Strategie d'impresa e capitale sociale, (with a foreword by F. Izzo), 2020.

66. F. Izzo, B. Masiello, Le fabbriche bianche. I processi di innovazione nelle imprese creative, 2020.

67. D. Salvatore, Saperi manageriali, crescita sostenibile e sud interno. Quali contributi possono offrire gli studi di organizzazione aziendale per una crescita economica sostenibile?, 2020.

68. P. Canonico, Understanding the role of knowledge in project settings, 2020.

69. I. Boncori, T. Loughran ${ }^{\mathrm{xx} I}$, Health and Wellbeing. The University of Essex Reader (with a foreword by A. Forster, 2020.

${ }^{x \times 1}$ Contributors Mario Bottone and Paolo Valerio; Christian Ballarin; Davide Bizjak and Cristiano Scandurra; Rossella Bonito Oliva; Giuseppe Burgio; Porpora Marcasciano; Mary Nicotra; Alessandra Riccio.

xхі Contributors Luigi Maria Sicca, Edoardo Mollona and Stefano Armenia; Nicola Andreottola, Simona Capecelatro, Davide Coppola; Sergio Barile and Francesca Iandolo; Mariavittoria Cicellin and Stefano Consiglio; Corrado Cuccurullo; Davide Bizjak, Paolo Canonico e Vito Lasala; Marcello Martinez and Mario Pezzillo Iacono; Stefano Mazzoleni and Francesco Giannino; Mario Nicodemi; Francesco Perillo; Francesco Piro; Apollonia Striano.

xxII Contributors Anthony Forster; Ilaria Boncori and Tracey Loughran; Martyna Śliwa; Charlie V.L. Smith; Lauren O'Connell; Abby Shovlin; Peter J. Martin and Edward M. Holt; Nileema Vaswani and Ilaria Boncori; Filippo Sinicato; 
70. J. Altmanova, L. Cannavacciuolo, M. Ottaiano, K. Russo (a cura di) ${ }^{x \mathrm{x}}$, Across the University. Linguaggi, narrazioni, rappresentazioni del mondo accademico, 2020.

71. M.T. Como, La Sala degli Angeli nel complesso conventuale di Suor Orsola Benincasa. Per una storia della costruzione, (with a foreword by L. d'Alessandro), 2020.

72. S. Cardone, Breviario di Pedagogia Teatrale (with a foreword by A. Bergamo), 2020.

73. E. Sacerdote, Legendary brands. Valutazioni e riflessioni strategiche, 2020.

74. C. Bruno, Gestire l'industria dell'emozione. Un'analisi manageriale dell'attività dei teatri lirici (with a foreword by G. Fraquelli), 2020

75. S. Consiglio e M. D'Isanto, La cultura muove il Sud (with an introduction by E. D'Errico, with a foreword by C. Borgomeo and with an afterword by G. Volpe), 2020.

76. G. Nolfe, L.M. Siccaxv, Mobbing. Narrazioni individuali e organizzative (with a foreword by B. Czarniawska and with an afterword by B. Poggio), 2020.

Jaime Lindsey; Ewen Speed, Susan McPherson and Peter Beresford; Francine Bailey; Sean Seeger.

xxiv Con scritti di Augusto Guarino, Maria Laudando, Maria Alessandra Giovannini, Giovanni Rotiroti, Ruth Amar, Valeria Sperti, Andrea Pezzè, Irma Carannante, Oriana Palusci, Antonio Saccone, Germana Volpe, Laura Cannavacciuolo, Giuseppina Notaro, Fabio Rodríguez Amaya, M. Cristina Lombardi, Marco Ottaiano, Franco Paris, Francesca De Cesare, Katherine Russo, Angela Buono, Anna Mongibello, Giovanni Agresti, Jana Altmanova, Giuliana Regnoli, Rosario Gallone, Vincenzo Bavaro, Federico Pio Gentile.

xxv Con scritti di Giovanni Nolfe, Luigi Maria Sicca, Gemma Zontini, Christophe Dejours; Giuseppe Recinto, Raffaello Santagata de Castro e Fabio Dell'Aversana, Mariapia Garavaglia; Luca Solari, Enzo Cordaro. 
Finito di stampare nel mese di settembre 2020 dalla Grafica elettronica - Napoli 